\title{
BINDINGS OF RARE BOOKS FROM THE COLLECTIONS OF THE ROMANIAN ACADEMY LIBRARY - A MULTIDISCIPLINARY STUDY
}

\section{Cristina CARȘOTE ${ }^{1}$, Luminița KÖVARI ${ }^{2}$, Carmen ALBU², Emanuel HADÎMBU ${ }^{3}$, Elena BADEA ${ }^{3,4^{*}}$, Lucreția MIU³ Gabriela DUMITRESCU}

${ }^{1}$ The National History Museum of Romania, 12 Calea Victoriei Street, 030026 Bucharest, Romania

${ }^{2}$ Department of Manuscripts and Rare Books, Romanian Academy Library, 125 Calea Victoriei Street, 010071 Bucharest,

Romania

${ }^{3}$ INCDTP - Division: Leather and Footwear Research Institute, 93 Ion Minulescu Street, 031215 Bucharest, Romania

${ }^{4}$ Department of Chemistry, Faculty of Sciences, University of Craiova, 107 I Calea București Street, 200512 Craiova, Romania

Received: 26.11 .2018

Accepted: 17.12 .2018

https://doi.org/10.24264/Ifj.18.4.6

BINDINGS OF RARE BOOKS FROM THE COLLECTIONS OF THE ROMANIAN ACADEMY LIBRARY - A MULTIDISCIPLINARY STUDY

ABSTRACT. This paper presents an overview of the conservation state of the tawed white leather, parchment and reused parchment bookbindings from the Rare Book Collection of the Romanian Academy Library. The transdisciplinary study was jointly conducted by the researchers of INCDTP-ICPI and Manuscripts and Rare Book Department of the Romanian Academy Library. Over 50 bindings in alum-tawed (white) leather, parchment and reused parchment were analyzed in situ using specific non-invasive or micro-invasive analysis methods such as visual and microscopic analyses, thermal microscopy (imageMHT method), attenuated total reflection (ATR), Fourier transform infrared spectroscopy (FTIR), and X-ray Fluorescence Spectrometry (XRF). Based on these results, conservation sheets have been drawn up including damage status, threats and conservation recommendations for each investigated bookbinding. Two conservation sheets are illustrated for alum-tawed and re-used parchment bindings. This is the first Romanian study dedicated both to the artistic and material aspects of rare book bindings so far.

KEY WORDS: bookbinding, alum-tawed leather, parchment, damage status, conservation reccommendations

LEGĂTURI DE CARTE RARĂ DIN COLECȚIILE BIBLIOTECII ACADEMIEI ROMÂNE - STUDIU MULTIDISCIPLINAR

REZUMAT. Această lucrare prezintă o imagine de ansamblu asupra stării de conservare a legturilor de carte din piele albă argăsită, pergament și pergament reutilizat din Colecția de Carte Rară a Bibliotecii Academiei Române. Studiul transdisciplinar a fost realizat în comun de către cercetătorii din cadrul INCDTP-ICPI și din cadrul Departamentului de Manuscrise și Cărți Rare al Bibliotecii Academiei Române. Peste 50 de legături din piele argăsită cu alaun (albă), pergament și pergament refolosit au fost analizate in-situ utilizând metode specifice de analiză neinvazivă sau microinvazivă, cum ar fi analize vizuale și microscopice, microscopie termică (metoda imageMHT), reflexie totală atenuată (ATR), spectroscopie în infraroșu cu transformată Fourier (FTIR) și spectrometrie de fluorescență de raze X (XRF). Pe baza acestor rezultate, au fost întocmite fișe de conservare, care includ starea de deteriorare, riscuri și recomandări de conservare pentru fiecare legătură de carte studiată. Două fișe de conservare sunt ilustrate pentru legături din pergament argăsite cu alaun și reutilizate. Acesta este primul studiu românesc de până acum dedicat atât aspectelor artistice, cât și aspectelor materiale ale legăturilor de carte rară.

CUVINTE CHEIE: legătură de carte, piele argăsită cu alaun, pergament, stare de deteriorare, recomandări de conservare

RELIURES DE LIVRES RARES DES COLLECTIONS DE LA BIBLIOTHÈQUE DE L'ACADÉMIE ROUMAINE - ÉTUDE MULTIDISCIPLINAIRE

RÉSUMÉ. Cet article présente une vue d'ensemble de l'état de conservation des reliures en cuir blanc tanné à l'alun, en parchemin et en parchemin réutilisé de la Collection de Livres Rares de la Bibliothèque de l'Académie Roumaine. L'étude transdisciplinaire a été menée conjointement par les chercheurs de I'INCDTP-ICPI et du Département des Manuscrits et des Livres Rares de la Bibliothèque de l'Académie Roumaine. Plus de 50 reliures en cuir (blanc) tanné à l'alun, en parchemin et en parchemin réutilisé ont été analysées in situ à l'aide de méthodes d'analyse non invasives ou micro-invasives telles que les analyses visuelles et microscopiques, la microscopie thermique (méthode imageMHT), la réflexion totale atténuée (ATR), la spectroscopie infrarouge à transformée de Fourier (FTIR) et la spectrométrie de fluorescence des rayons X (XRF). À partir de ces résultats, des fiches de conservation ont été élaborées, indiquant notamment l'état de détérioration, les menaces et les recommandations de conservation pour chaque reliure explorée. Deux fiches de conservation sont illustrées pour les reliures en parchemin tanné à l'alun et réutilisé. Cet article est la première étude roumaine consacrée à la fois aux aspects artistiques et matériels des reliures de livres rares.

MOTS CLÉS : reliure, cuir tanné à l'alun, parchemin, l'état de détérioration, recommandations en matière de conservation 


\section{THE RARE BOOK COLLECTION OF THE ROMANIAN ACADEMY LIBRARY}

The Rare Book Collection, established since 1958, by the selection of volumes from the General Book Fund of the Academy Library, brings together 11626 copies of Romanian and foreign prints, grouped chronologically and by bibliophilia criteria, such as the rarity of editions, the richness and quality of the illustrations, the special materials on which they were printed, the trademarks of different types, the precious bindings. The collection reflects the entire evolution of book printing, from the beginning to the present day, for the entire European space and its most important printing centers. The Rare Book Fund is also a collection of bindings, with notable examples for each epoch, reflecting both the artistic and ideological vision of the moment. Over 50 white leather and parchment bindings have been the subject of this study. They make up a distinctive group, with its own physical, structural and ornamental characteristics, in the valuable rare book collection of the Academy Library.

\section{BOOKBINDING}

The main function of a binding is to keep together the sheets/bundles of a manuscript or a book. In addition, the binding provides protection against mechanical stresses. Not seldom the binding fulfills an aesthetic, beautifying role, being a distinctive feature of the owner. By the nature of the materials and the ornamentation techniques used, the bindings are equally the expression of socio-cultural tendencies and of the artistic vision of each age. Moreover, a detailed analysis of the binding can reveal exceptional information about the material processing technologies, contributing to the improvement and expansion of dating and localization studies. The material elements of the covers, long undervalued, represent an invaluable source of information, with an exceptional potential to complement knowledge and understanding of history in all its aspects. For conservators and restorers, knowledge about the nature of materials and manufacturing technologies are essential tools, in the absence of which changes due to conservation conditions or a determined treatment over the general "balance" of the "book system" cannot be assessed.
The disregard of the material elements of the covers has led to the loss of most of the old bindings due to the campaigns of rebinding and restoration made during the first half of the 20th century. In Europe, massive restoration interventions, during which curators' attention focused exclusively on text or decorative portions of the cover, allowed restorers to eliminate parts without text or decorations. Thus, in the case of so-called artistic covers, fragments were preserved, while the covers lacking textual or graphic components were almost totally lost. A modern and responsible approach to surviving bindings must therefore start from the identification of the constituent materials of the structural elements of bindings, their in situ characterization by non-invasive techniques (where micro-sampling is possible, micro-destructive analyses can contribute with very useful quantitative information), assessing the degree of deterioration, drawing up the conservation sheet and developing a long-term monitoring program. The conservation sheet is the starting point for any decision regarding the selection of the optimal conditions (temperature, relative humidity, illumination, maximum concentration allowed for atmospheric pollutants and volatile organic substances) for preservation, exposure, consultation and manipulation, as well as the choice of conservation or restoration treatments based on the specific characteristics and damage of each binding. It is important to emphasize that not all bindings require conservation or restoration interventions, let alone radical treatments with a high risk of damaging both the information contained therein and the longevity of the binding.

In Romania, there are very few studies dedicated to bookbindings, whose main objective is the study of ornamental schemes (Studite project - Study and Creation on Byzantine Bookbindings [1], 2011-2013, coordinated by the Book Conservation Center of Arles, within which the Byzantine bindings of Greek [2] and Slavic manuscripts from the collection of the Romanian Academy Library were identified and studied, and 10 replica bindings were made, respecting the elements of structure, technique and 
ornamentation of the Byzantine bindings) or medieval book fastenings [3] in the archaeological discoveries of Transylvania. This is the very first study dedicated both to the artistic and material aspects of rare bookbindings so far.

\section{Ornaments for White Leather Bookbinding}

White leather bindings are made of pig, sheep or calf skin treated with aluminum salts, on wooden boards, and more rarely on cardboard bark, wooden supports being used until late in the $17^{\text {th }}$ century, especially on German territory. This is where plate-decorated bindings largely come from (a technique that appeared in the $13^{\text {th }}$ century in Holland), with which portrait ornaments are made, depicting personalities of the time: great figures of the Reformation era, such as Martin Luther, Philip Melanchton, Erasmus of Rotterdam, Jan Hus (for example, in the binding of some New Testament editions, printed in Hagenau in 1521, in Geneva in 1590, a 1591 edition of the Bible, published in Frankfurt, or in the binding of the work Thomae
Linacri Britanni De emendata structura Latini sermonis, Leipzig, 1545 - Figures 1-3); historical personalities such as Charles $\mathrm{V}$ (Chronicon Carionis, Wittenberg, 1580, Figure 4, Florilegium diversorum epigrammatum veterum, Genevae, 1566, Vita Jacobi despotae, Wittenberg, 1587), Maximilian II (Florilegium diversorum epigrammatum veterum, Geneva, 1566), or German princes of the various Länder, among which Johann Friedrich I, Prince of Saxony, is distinguished by his numerous appearances: Commentariorum C. Iulii Caesaris De bello gallico, Frankfurt, 1584, Chronicon Carionis, Wittenberg, 1580, M. T. Ciceronis Orationum volumen tertium, Strasbourg, 1574 (Figure 5).

Portraits placed on the back covers sometimes correspond to the blazons of the historical character, the noble family, the Land or city of origin. The borders of these bindings also have a historical character, made with Reformer Roll ornaments, an enclosed frame, comprising miniature portraits of representatives of the Reformation Age (P. Ovidii Nasonis Opera quibus in omnes Metamorphoseos ..., Basel, 1556, Figure 6).

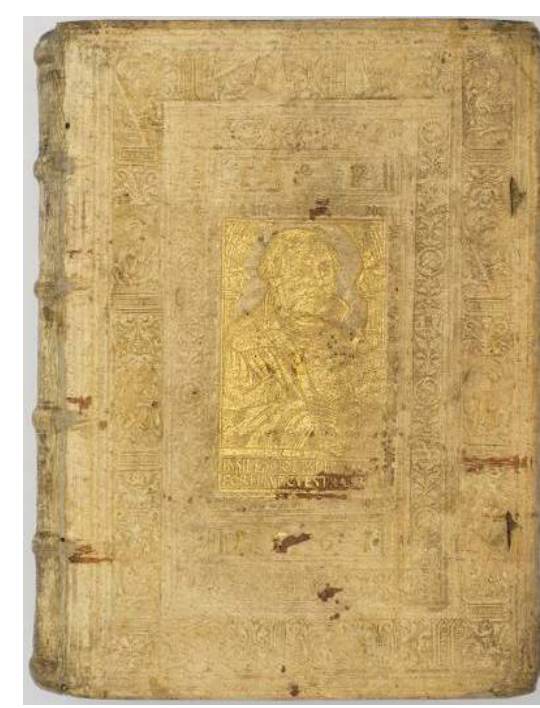

Figure 1. New Testament, Hagenau, 1521

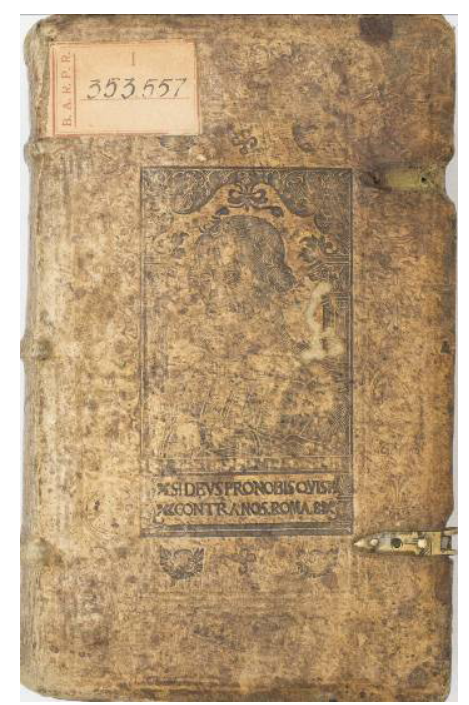

Figure 2. New Testament, Geneva, 1590

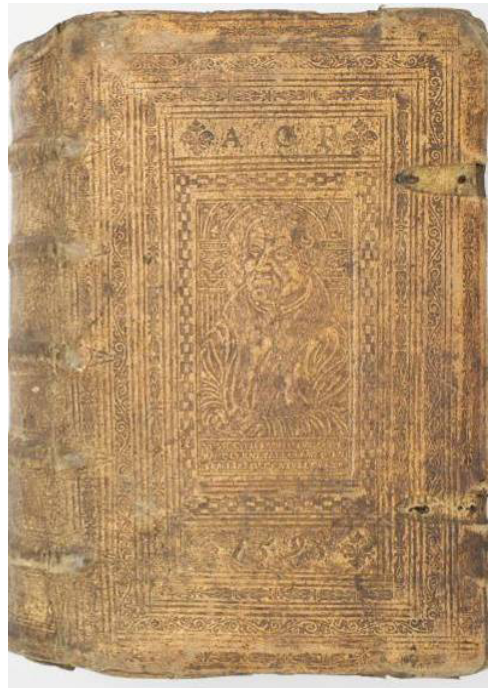

Figure 3. Bible, Frankfurt, 1591 


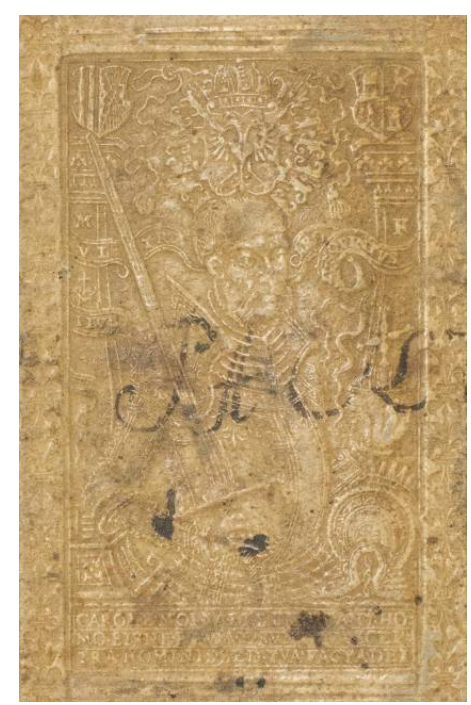

Figure 4. Chronicon Carionis, Wittenberg, 1580

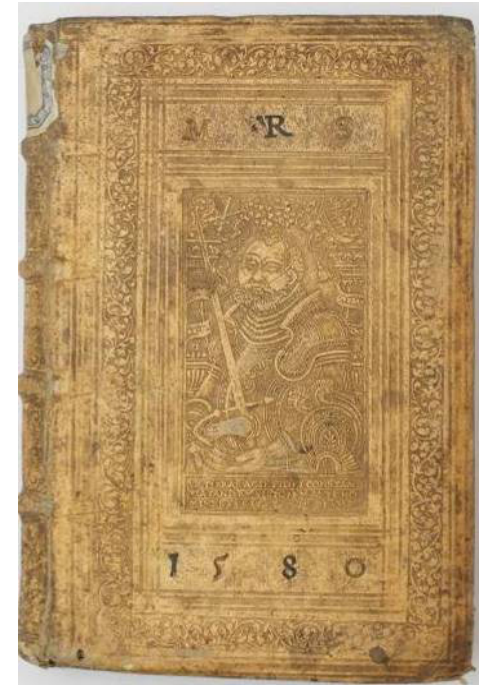

Figure 5. M. T. Ciceronis Orationum..., Strasbourg, 1574

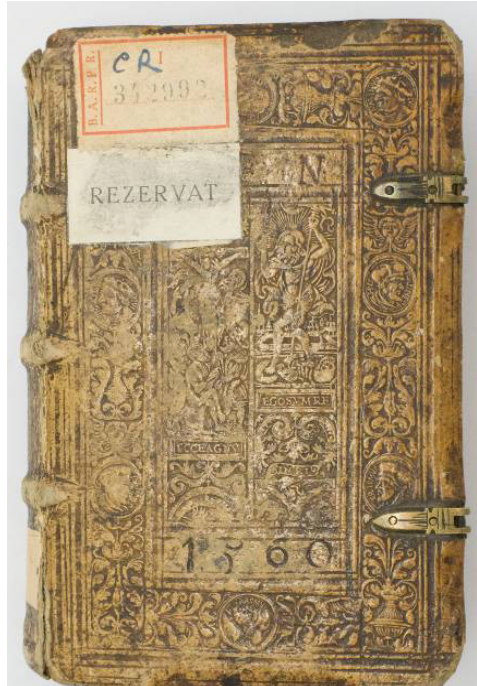

Figure 6. P. Ovidii Nasonis Opera

... Metamorphoseos ..., Basel, 1556
The theme of central rectangular panels, as well as of the segmented borders, may be the allegory of Christian or celestial virtues established by the ideology of the epoch, but taking on elements from the vision of Plato or other classical thinkers: cardinal virtues among which prudence (prudentia), temperance (temperantia), courage (fortitudo), justice (justitia), and theological virtues, among which faith (fides), hope (spes), love/charity (caritas). These moral traits, defining the profile of the perfect Christian, are allegorically portrayed as feminine characters, accompanied by canonical symbolic objects and therefore easily decipherable, such as the scales and sword for Justice (Homērou Odysseia..., Strasbourg, 1572, Thucydides, De bello peloponnesiaco ..., Wittenberg, 1562), the wheel of Fortune (Ulpianus, Iustiniani Institutionum, Geneva, 1578), hands clasped together in prayer for Hope and Faith, or are suggested by situations of clear significance, such as offering bread to an old man to symbolize Charity or Mercy (Euripide, Tragōdiai oktōkaideka ..., Basel, 1551).

However, to represent these qualities, characters from the biblical text or from ancient history, which have become emblematic for a certain character trait, are used: the wife of Lucius Tarquinius Collatinus, Lucretia, is a symbol of moral purity, fidelity and dignity (De Philippi Melanchthonis ortu, totius vitae curriculo, Leipzig, 1566, Nicodemi Frischlini Balingensis, Hebraeis. Continens duodecim libros ..., Strasbourg, 1610), while Judith, a veterotestamentary character who decapitates Holofern, is the incarnation of courage, strength and faith, in the service of the community.

The great iconic Christian themes, from the Christic and Marianic cycles, are also found in the ornamentation of the time: Crucifixion and Resurrection (P. Ovidii Nasonis Opera quibus in omnes Metamorphoseos ..., Basel, 1556), Annunciation and Resurrection (Alessandro Guagnini, Rerum Polonicarum ..., Frankfurt, 1584). There are also Old Testament themes in combination with the novotestamentary ones: Adam and Eve in Heaven, Moses and the Tablets of the Law.

However, there are many bookbindings with non-figurative ornamentation, whose inventory includes only varied phytomorphic and geometric elements, from the phytomorphic network border to small individual elements representing stylized inflorescences placed in the center panel.

Another feature of the white leather bookbindings on wooden boards, especially German ones, is the printing of the binding year and the initials of the owner, essential items for dating and volume circulation. 


\section{Ornaments for Parchment Bookbindings}

Among the specific features of parchment bindings is the use of cardboard barks or even the lack of any support, which gives them a lower weight and greater maneuverability, being called limp binding (reliure flexible) or Dutch bindings, for the place where they were established, at the end of the sixteenth century and the beginning of the seventeenth century, although they had been known since the previous centuries.

Ornamentation is often sober and simple, but elegant and refined using the golden leaf process. Many of the parchment bindings are decorated with a single central polylobate medallion with oriental geometric motifs (arabesques) with phytomorphic or heraldic motifs. From this last subtype the binding with the coat of arms of LouisAntoine de Noailles, archbishop and cardinal of Paris (Anastasius Bibliothecarius, Historia Ecclesiastica ..., Paris, 1649, Figure 7) or the binding with the emblems of Maximilian Erasmus von Hacklberg Gallois, Traité des plus belles bibliothèques de l'Europe..., Paris,
1685) stand out. Bindings with the heraldic emblems of some cities, such as Rotterdam and Regensburg can also be found.

Spectacular through the richness and polychromy of the decor, made by pressing and then painted, are the bindings of the Bauern Einbände (peasant binding, reliure folklorique allemande ( de paysan) originating in Hungary and then spread to Germany, the Netherlands and the northern countries, in the $17^{\text {th }}-18^{\text {th }}$ centuries. The folk-style motifs are mostly floral and plant, filling the entire space of the covers and drawing attention through the vivid color of the pastels. They are often the framework in which the fundamental religious scenes, Crucifixion and Virgin Mary with the Child, are integrated, also placed in compositions with geometrical motifs, in which the bands serving as borders or arcs marking the corners are highlighted by different colors. Many of the volumes that keep these bindings are New Testament editions (two editions printed at Leyda, 1765 and 1785, an edition published in Halle in 1710, of this last edition the library contains two copies, Figures $8 \mathrm{a}$ and $8 b$ ).

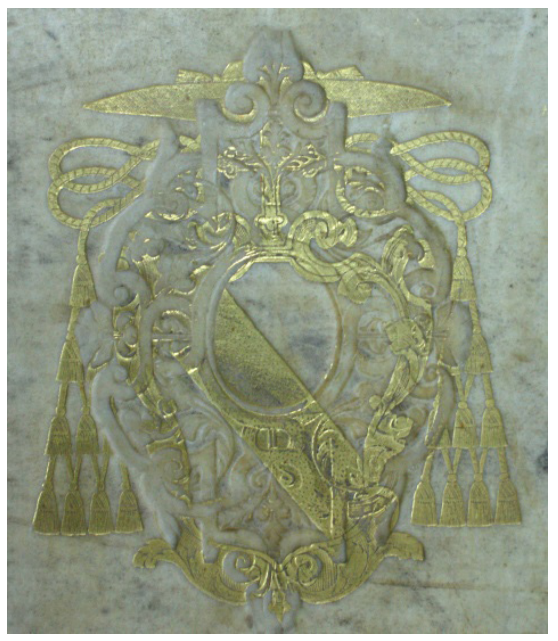

Figure 7. Anastasius

Bibliothecarius, Historia

Ecclesiastica ..., Paris, 1649

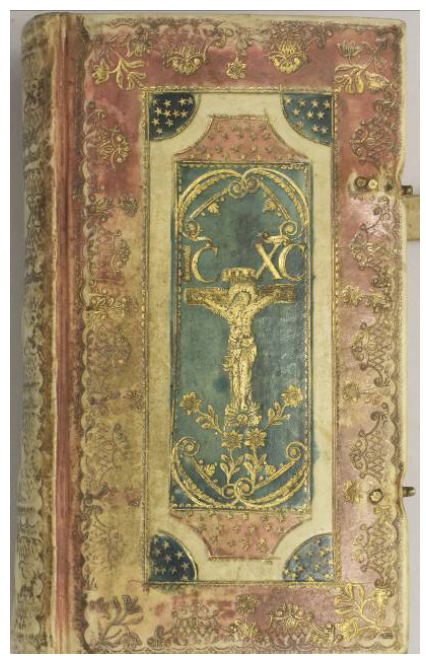

Figure 8a. New Testament, Leyda, 1765 (copy 1)

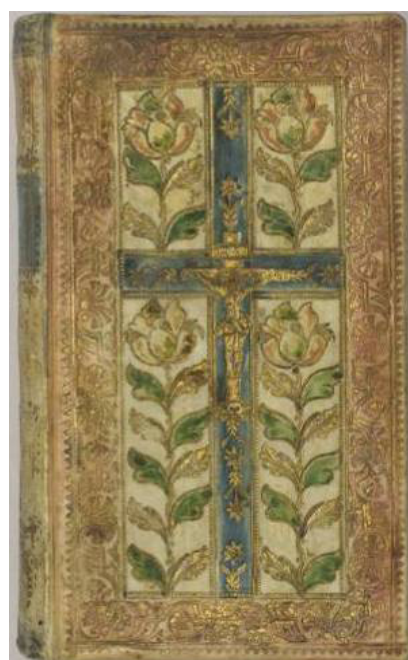

Figure 8b. New Testament, Leyda, 1785 (copy 2) 


\section{Reused Parchment Bookbindings}

The third type of binding analyzed was that of the reused parchment bindings, valuable for the age of the parchment, the variant of the text, or the graphs used. Among the most important ones are a sheet with a fragment of St. Augustine's texts, originally included in a Homiliarium or a Breviary (binding for an edition of Lambert Daneau's

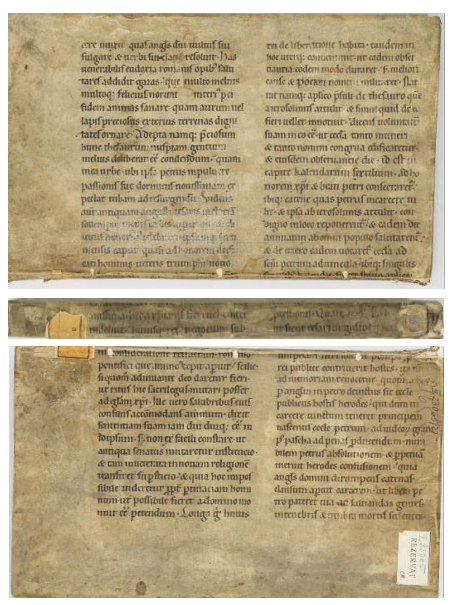

The white alum-tawed leather and parchment bindings represent a well-defined corpus of the rare books collection, in terms of leather appearance, manufacturing techniques, combining with the other structural elements of the book, and inventory and ornamentation techniques.

\section{In situ Analysis of Bookbindings}

Over 50 bindings in white leather, parchment and reused parchment from the Rare Book Collection of the Romanian Academy Library were analyzed in situ using specific analysis methods. Based on the results obtained conservation sheets were drawn up. The in situ analysis performed and two selected conservation sheets are presented below.

The visual analysis was based on the macroscopic and microscopic analysis protocol for both surfaces of the leather or parchment (corium - flesh side and grain hair follicle side) developed in the Improved Damage Assessment of Parchment (IDAP) European project $[4,5]$. The protocol seeks to work, Elenchi ereticorum, printed in 1560 in Geneva), another parchment sheet taken from a copy of the lexicon made by Giovanni Balbi (link to Vindiciae contra tyrannos..., published in Basel in 1579) or a parchment sheet with a fragment from Vita Sancti Petri, in Carolingian writing (dressing a volume of Annales Sultanorum Othmanidarum, printed in Frankfurt in 1596, Figure 9).

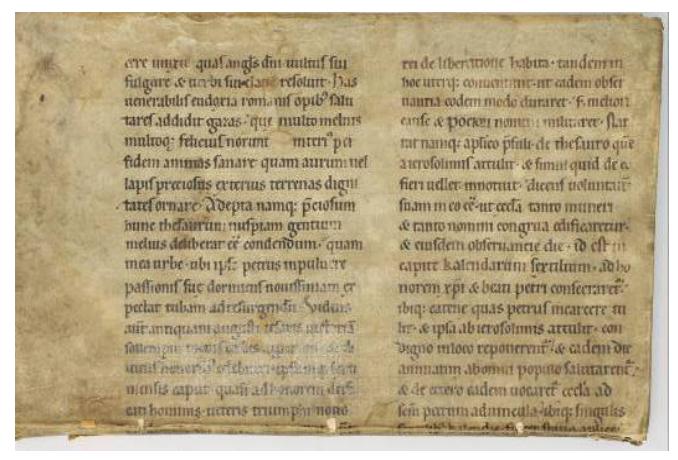

Figure 9. Annales Sultanorum Othmanidarum, Frankfurt, 1596

gather information on (i) the animal species used for the manufacture of leather or parchment; (ii) aspects concerning the skin processing technique; (iii) damage caused by physical, chemical and biological factors or improper handling; (iv) the types of inks and pigments applied to the support, and ( $v$ ) the ink and pigment conservation state [68]. The microscopic observations were made with a Dino-Lite digital microscope, model AD7013MZT, 1.3 Megapixel resolution.

Attenuated Total Reflection Infrared Spectroscopy (FTIR-ATR) is one of the most widely used methods of analysis in modern conservation and restoration laboratories, being non-destructive, versatile and fast. The technique is based on vibration-rotation transitions that occur at the molecular level by infrared radiation absorption. The recorded spectrum contains information on the main characteristic frequencies of specific functional groups in the molecule to be analyzed, and by its interpretation substances can be identified and structural changes at 
the molecular level can be detected. In the case of leather and parchment, FTIR-ATR allows the detection and quantification of structural changes in molecular collagen as well as the identification of materials added in the manufacturing process or subsequently formed in deterioration and/ or aging processes [6-9].

FTIR-ATR analyses were performed in a non-destructive manner, directly on the cover, using an Alpha portable spectrometer (Bruker Optics) equipped with the Platinium diamond ATR accessory. The spectra were recorded in the spectral range $4000-650 \mathrm{~cm}^{-1}$ at a resolution of $4 \mathrm{~cm}^{-1}$ using 32 scans. OPUS 7.0 software was used for spectra processing and evaluation.

Thermal microscopy known as the Micro Hot Table (MHT) method is a combined technique based on the microscopic analysis of collagen fibers subjected to controlled heating (heating speed: $2^{\circ} \mathrm{C} /$ minute) in the temperature range $(20-100)^{\circ} \mathrm{C}$. Collagen materials have an intrinsic property of shrinking when subjected to heating in an aqueous medium, reducing their length to a quarter of the original. The temperature at which the shrinking begins, the one at which the fibers contract simultaneously and the one at which shrinking is completed are indicators on the basis of which the hydrothermal stability and structural heterogeneity of the collagen fibers [10-13] are evaluated.

Microsamples (0.05-0.1 mg) of the material taken from the damaged areas of the bookbindings (where sampling was possible) were analyzed in the Advanced Cultural Heritage Research Laboratory (ARCH Lab) using a system consisting of a heating microplate LTS 120 (Linkam Scientific Instruments) equipped with an automatic heating rate control system and a Nikon 1000 SMZ 745 stereomicroscope equipped with a Nikon D90 digital camera. Image acquisition and interpretation was done with imageMHT software.
X-ray Fluorescence Spectrometry (XRF) is an elemental, non-destructive and rapid analytical technique that is used to determine the elemental composition of materials. A major advantage of this technique is the availability of portable systems and the possibility of in situ analysis of objects of interest without any prior training.

XRF measurements were performed to identify pigments and precious materials in the decorations of the bookbindings as well as the materials added to the manufacturing process. For the detection of chemical elements with atomic number $Z>12$, an ED-XRF Elio (XGLab) portable spectrometer with a $1 \mathrm{~mm}$ analysis spot size, equipped with an excellent resolution SDD (Silicon Drift Detector), integrated video camera and laser-based alignment.

\section{Conservation Sheet for a White Leather Bookbinding}

\section{Call number: C. R. II 46586}

Author: Francofurdi (Frankfurt), Impensis Samueli Selfischii \& Bechtoldi Rab

Editors: Selfisch, Samuel // Rab, Bechtold

[11], 981 [-992] f., 2 h.; il.; in $4^{\circ}(20 \mathrm{~cm})$

Title page: Bibliorum codex sacer et authenticus, Testamenti utriusque Veteris \& Novi, ex Hebraea \& Graeca veritate, quàm proximè ad literam quidem fieri potuit, fidelissimè translatus in linguam Latinam...

Dating: 1591

Pagnino, the Saint 1470-1541, trad. // Bèze, Théodore de 1519-1605, trad.// Baduel, Claude 1491-1561 trad.

Bookbinding type: wooden bark covered in alum-tawed leather (Figure 10), dyed

\section{Microscopic and Macroscopic}

\section{Characteristics}

-Microscopic identification of the animal - pigskin

-Microscopic view (Figure 11): yellow-brown color 
with areas showing discoloration, mechanical damage, flaking, fraying, dirt adhesion to the surface and various dark spots; the clasps are missing
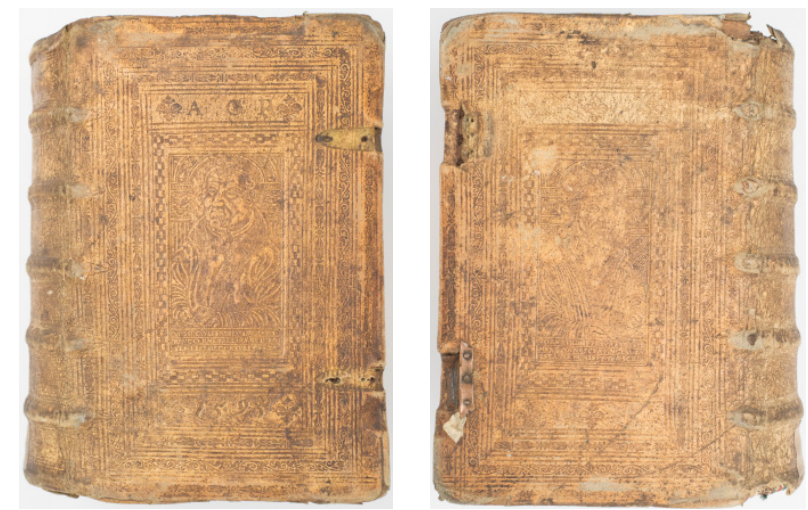

Figure 10. Overview of the leather bookbinding: recto (left image) and verso (right image)

\section{Hydrothermal Stability of Leather Determined by MHT Method}

$$
\text { MHT parameters indicating }
$$

hydrothermal stability $\left(T_{\mathrm{s}}-\right.$ shrinkage temperature, $T_{f}$ - the temperature when the first fiber shrinks, $T_{1}$ - the temperature
-Microscopic view (morphology) of waterdispersed fibers, most of the fibers exhibit good cohesiveness, the tendency to lose the helical character and to be flattened is reduced.
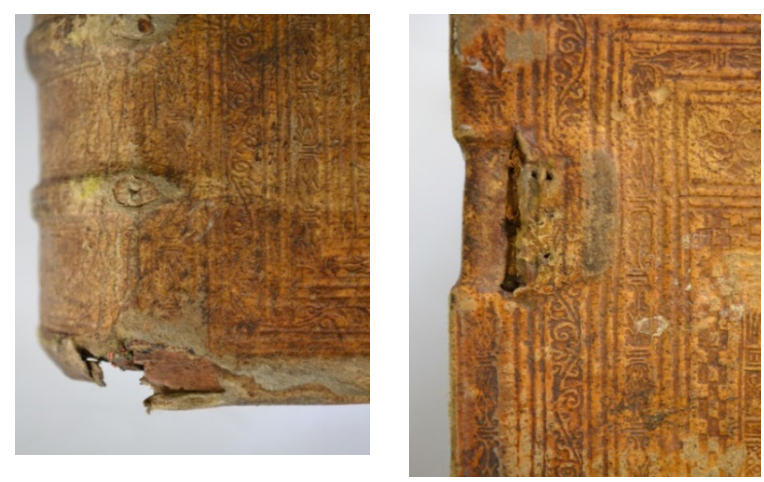

Figure 11. Macroscopic details illustrating mechanical damage of the bookbinding in the area of the spine and clasp

when the last fiber shrinks) and structural heterogeneity $(C$ - the main shrinkage interval, $\Delta T$ - total shrinkage interval) for a white leather micro-sample taken from a damaged area of the bookbinding are shown in Table 1.

Table 1: MHT parameters for a white leather sample taken from the bookbinding and for a new alum-tawed leather

\begin{tabular}{|c|c|c|c|c|c|}
\hline \multirow{2}{*}{$\begin{array}{l}\text { Sample } \\
\text { Parameters }\end{array}$} & \multicolumn{3}{|c|}{ Hydrothermal stability } & \multicolumn{2}{|c|}{ Structural heterogeneity } \\
\hline & $\mathrm{T}_{\mathrm{s}} /{ }^{\circ} \mathrm{C}$ & $\mathrm{T}_{\mathrm{f}} /{ }^{\circ} \mathrm{C}$ & $\mathrm{T}_{1} /{ }^{\circ} \mathrm{C}$ & $\mathrm{C} /{ }^{\circ} \mathrm{C}$ & $\Delta \mathrm{T} /{ }^{\circ} \mathrm{C}$ \\
\hline $\begin{array}{l}\text { New leather } \\
\text { II } 46586\end{array}$ & $\begin{array}{c}63.8 \pm 0.3 \\
55.4\end{array}$ & $\begin{array}{c}53.2 \pm 0.4 \\
47.0\end{array}$ & $\begin{array}{c}79.8 \pm 0.4 \\
88.3\end{array}$ & $\begin{array}{c}5.3 \pm 0.2 \\
7.3\end{array}$ & $\begin{array}{c}31.6 \pm 0.6 \\
32.9\end{array}$ \\
\hline
\end{tabular}

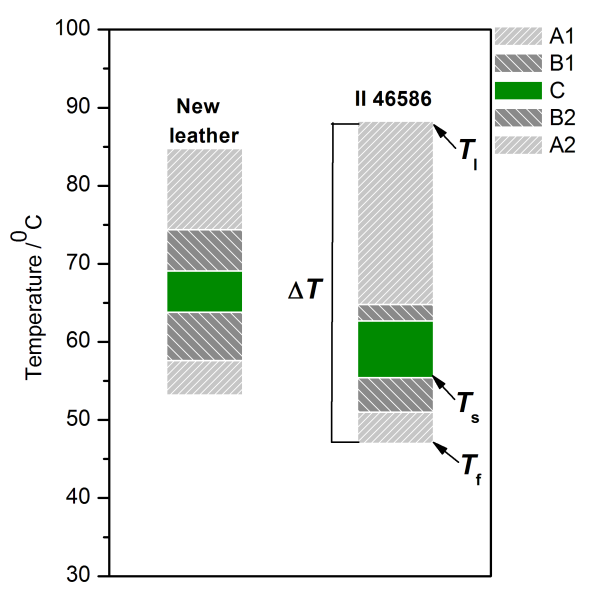

Figure 12. Graphic illustration of shrinkage intervals (A1, B1, C, B2, A2), highlighting MHT parameters for the leather sample taken from the cover and for a new alum-tawed leather. Assessment of deterioration degree [12]: undeteriorated parchments, $\mathrm{T}_{\mathrm{f}}>45^{\circ} \mathrm{C} ; \mathrm{T}_{\mathrm{s}}>50^{\circ} \mathrm{C}$; parchments with minor deterioration degree, $40{ }^{\circ} \mathrm{C}<\mathrm{T}_{\mathrm{f}}<45^{\circ} \mathrm{C} ; 45^{\circ} \mathrm{C}<\mathrm{T}_{\mathrm{s}}<50^{\circ} \mathrm{C}$; parchments with medium deterioration degree, $35^{\circ} \mathrm{C}<\mathrm{T}_{\mathrm{f}}<40^{\circ} \mathrm{C} ; 40^{\circ} \mathrm{C}<\mathrm{T}_{\mathrm{s}}<45^{\circ} \mathrm{C}$; parchments with major deterioration degree, $\mathrm{T}_{\mathrm{f}} \leq 35^{\circ} \mathrm{C} ; \mathrm{T}_{\mathrm{s}} \leq 40^{\circ} \mathrm{C}$ 
According to the criteria for classification of the deterioration degree based on $T_{\mathrm{s}}$ and $T_{\mathrm{f}}$ parameters [12], the bookbinding shows a minor degree of deterioration. However, the structural heterogeneity of the leather is quite high compared to that of the new leather, suggesting the presence of several collagen populations with distinct thermal stability: collagen "stabilized" by reaction with aluminum salts, "free" collagen, resulting from the "detanning" process and "destabilized" collagen, resulting from hydrolytic and oxidative processes. The thermally unstable, pregelatinized and gelatinized fractions of collagen are susceptible to being affected by high and/or oscillating relative humidity $(\mathrm{RH})$ in the storage, consultation or exposure space, as well as wet conservation or restoration treatments.

Risk of exposure to wet treatments: solubilization of unstable fractions, formation of sticky appearance areas, loss of collagen material.

Risk of exposure to oscillating $R H$ : crack formation, superficial cracks (craquelé appearance), loss of collagen material.

\section{Molecular Changes and Added Materials Identified by FTIR-ATR - Figure 13}

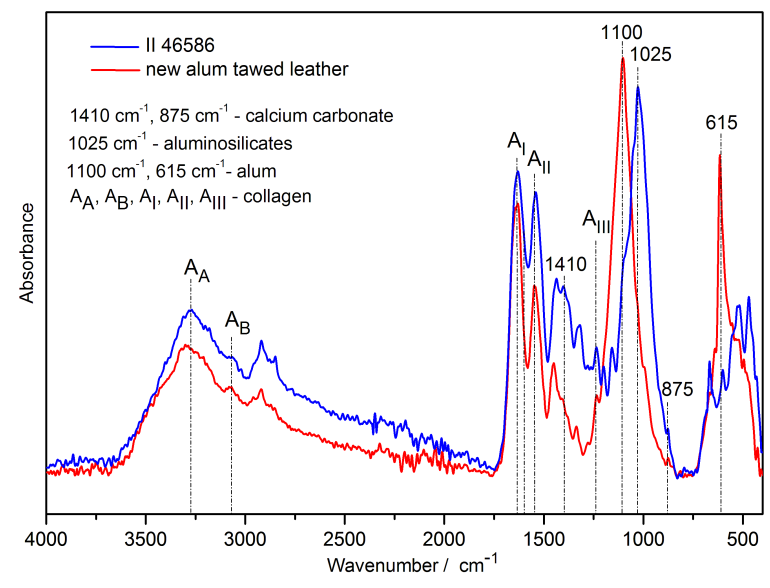

Figure 13. FTIR-ATR spectrum of the leather cover (II 46586) compared to that of new alum-tawed leather. The main absorption bands of collagen are highlighted (AA, AB, Al, All, AlII), as well as those attributed to calcium carbonate, alum and aluminosilicates

- calcium carbonate: comes from the manufacturing process

- alum: the tanning agent
- aluminosilicates: dust (dirt) adhering to the surface of the cover - low $A / A_{1 \mid}$ ratio: indicates the hydrolytic cleavage of peptide bonds of collagen

\section{Materials Added to Leather Identified by XRF - Figure 14}

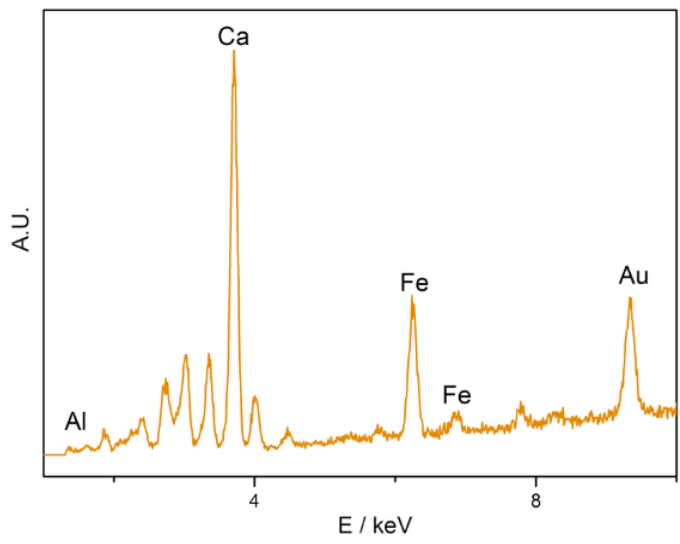

Figure 14. XRF spectrum of leather cover (II 46586). Goethite (Fe) - yellow-brown pigment used in cover decoration; Gold - letters applied to the leather cover. The presence of calcium carbonate and alum is confirmed. 


\section{Conservation Sheet for a Reused Parchment Bookbinding}

Call number: C. R. I 39622

Author: Daneau, Lambert 1530 - 1595/ Vignon, Eustache 1530 - 1588 |4 tip.

Editor: Genevae, Apud Eusthatium Vignon 1580 [4] f., $162[-167]$ p. in $8^{\circ}(180 \times 117 \mathrm{~mm})$

Title page: Elenchi haereticorum. Ubi facili et singulari methodo explicatur qua ratione haereticorum paralogismi deprehendi et solui possint. Liber omnibus Evangelicae veritatis studiosis valde necessarius If Lamberto Danaeo authore, a quo nunc primum auctus que recognitus cum Indice locupletissimo

Dating: 1580

Polemic theology// dialectics

Bookbinding type: reused parchment, written in black, red and blue ink (Figure 15)
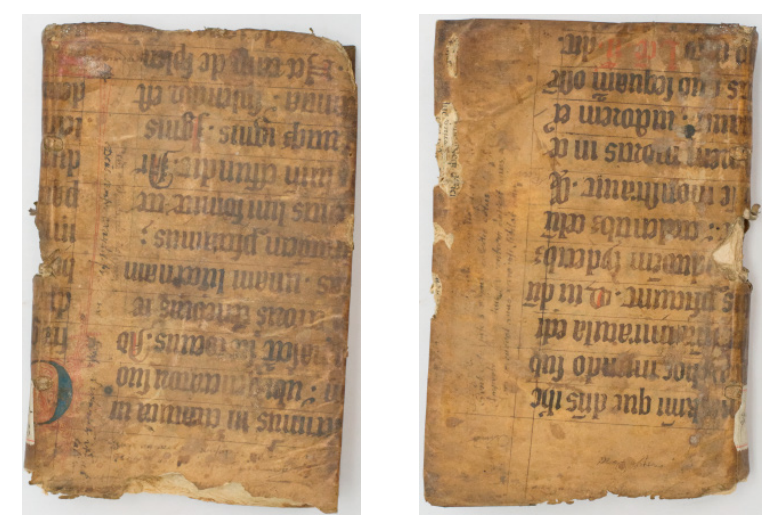

Figure 15. Overview of the reused parchment cover: recto (left image) and verso (right image)

\section{Macroscopic and Microscopic Characteristics}

-Microscopic identification of the animal species: calfskin

-The macroscopic view shows mechanical damage, marginal fraying, dirt adhering to the surface, spots of different nature (water or other liquids, lime) and foxing (Figures $16 a$ and $2 b$ )

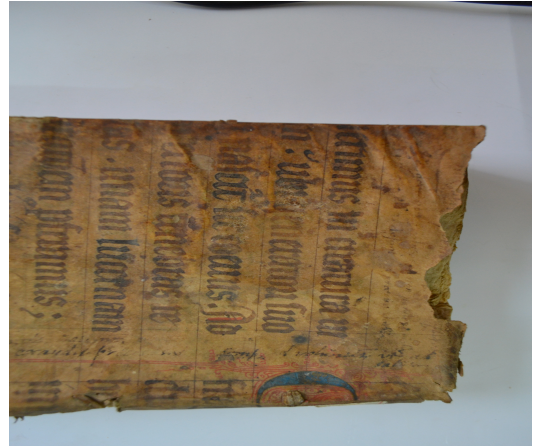

(a)
-Microscopic view (the morphology) of waterdispersed fibers, the majority of fibers exhibit good cohesiveness, the tendency to lose their helical character and to flatten is minimal. No gelatinous fibers and no fragmented fibers are observed.

-Microscopic view of inks: black ink is slightly discolored, blue ink is exfoliated, while red ink is well preserved (Figures 16c and 2d).

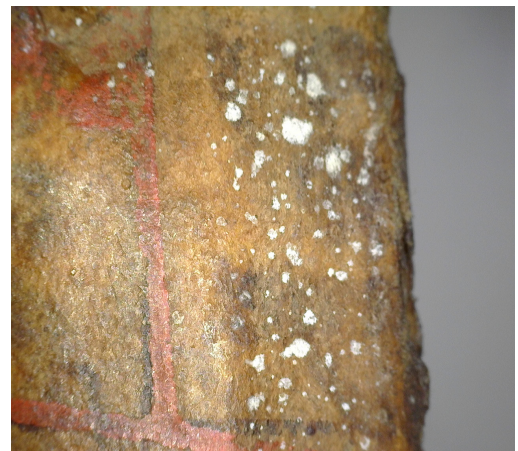

(b) 


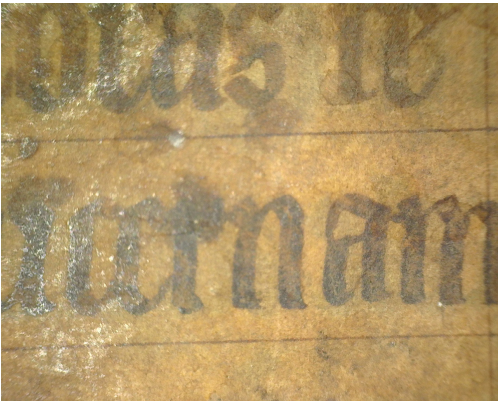

(c)

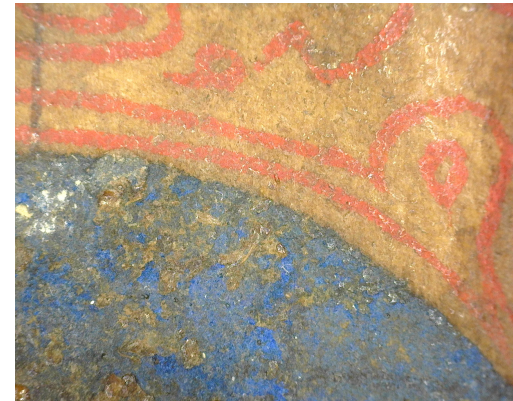

(d)

Figure 16. (a) Macroscopic image illustrating adherent dirt and various stains on the parchment surface. Microscopic images illustrating: (b) lime spots on the parchment surface; (c) slightly discoloured black ink; (d) exfoliated blue ink and well-preserved red ink.

\section{Hydrothermal Stability of Parchment Determined by MHT Method}

MHT parameters indicating hydrothermal stability $\left(T_{s}\right.$ - shrinkage temperature, $T_{f}-$ the temperature when the first fiber shrinks, $T_{1}$ - the temperature when the last fiber shrinks) and structural heterogeneity $(C$ - the main shrinkage interval, $\Delta T$ - total shrinkage interval) for a parchment sample taken from a damaged area of the cover are presented in Table 2 in comparison with those corresponding to a new parchment.

Table 2: MHT parameters for a parchment sample taken from the cover and for a new parchment

\begin{tabular}{lccccc}
\hline Sample & \multicolumn{3}{c}{ Hydrothermal stability } & \multicolumn{2}{c}{ Structural heterogeneity } \\
& $\mathrm{T}_{\mathrm{s}} /{ }^{\circ} \mathrm{C}$ & $\mathrm{T}_{\mathrm{f}} /{ }^{\circ} \mathrm{C}$ & $\mathrm{T}_{1} /{ }^{\circ} \mathrm{C}$ & $\mathrm{C} /{ }^{\circ} \mathrm{C}$ & $\Delta \mathrm{T} /{ }^{\circ} \mathrm{C}$ \\
\hline New parchment & $58.4 \pm 0.4$ & $52.8 \pm 0.5$ & $72.0 \pm 0.4$ & $5.4 \pm 0.9$ & $19.2 \pm 0.9$ \\
I 39622 & 46.9 & 35.3 & 79.0 & 10.1 & 43.7 \\
\hline
\end{tabular}

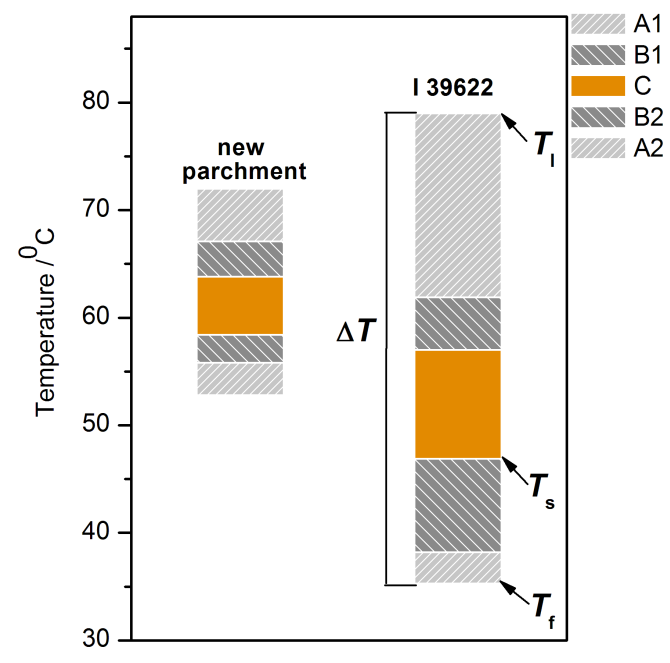

Figure 17. Graphic illustration of shrinkage intervals (A1, B1, C, B2, A2), highlighting MHT parameters for the parchment sample taken from the cover and for a new parchment. Assessment of deterioration degree [12]: undeteriorated parchments, $\mathrm{T}_{f}>45^{\circ} \mathrm{C} ; \mathrm{T}_{s}>50^{\circ} \mathrm{C}$; parchments with minor deterioration degree, $40^{\circ} \mathrm{C}<\mathrm{T}_{f}<45^{\circ} \mathrm{C} ; 45^{\circ} \mathrm{C}<\mathrm{T}_{s}<50^{\circ} \mathrm{C}$; parchments with medium deterioration degree, $35^{\circ} \mathrm{C}<\mathrm{T}_{f}<$ $40{ }^{\circ} \mathrm{C} ; 40{ }^{\circ} \mathrm{C}<\mathrm{T}_{\mathrm{s}}<45^{\circ} \mathrm{C}$; parchments with major deterioration degree, $\mathrm{T}_{\mathrm{f}} \leq 35^{\circ} \mathrm{C} ; \mathrm{T}_{\mathrm{s}} \leq 40^{\circ} \mathrm{C}$ 
According to the classification criteria for the degree of deterioration according to the parameters $T_{s}$ and $T_{f}$, the cover of the parchment presents a minor degree of deterioration. However, the structural heterogeneity of the parchment is very high compared to that of a new parchment (Figure 17), indicating the presence of several collagen populations with distinct thermal stabilities, including thermally unstable, pregelatinized and gelatinized collagen fractions [14].

Keeping it under controlled temperature and relative humidity conditions is recommended. Conservation or restoration interventions, especially wet treatments, are not recommended.

\section{Molecular Changes and Added Materials Identified by FTIR-ATR - Figure 18}

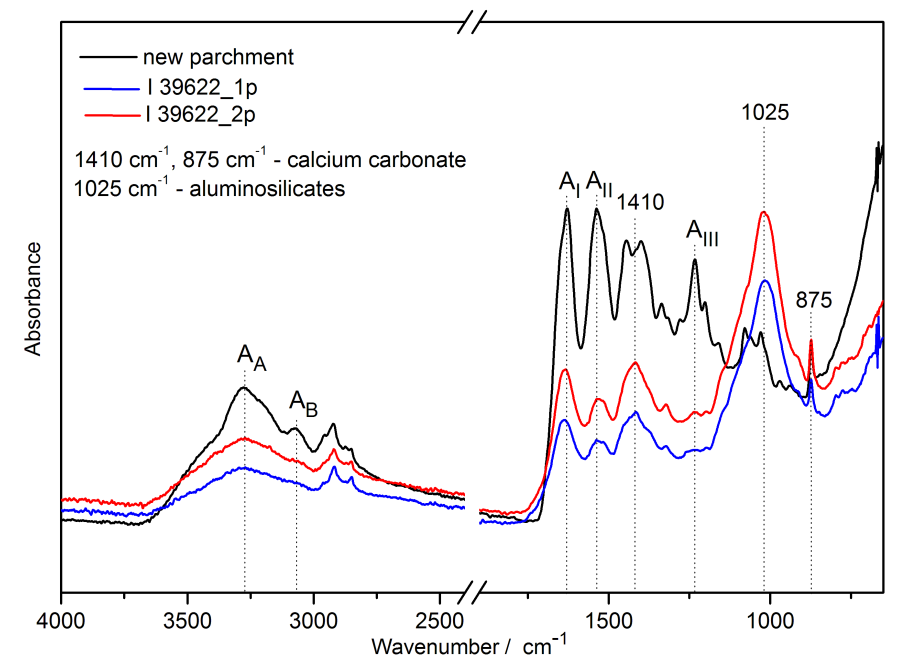

Figure 18. FTIR-ATR spectra recorded for 2 parchment samples taken from the cover and for a new parchment. The main absorption bands of collagen are highlighted $\left(A_{A^{\prime}}, A_{B^{\prime}}, A_{l^{\prime}}, A_{\| \prime}, A_{\| I I}\right)$, as well as those attributed to calcium carbonate, alum and aluminosilicates.

- calcium carbonate: originats from the manufacturing process

- aluminosilicates: dust (dirt) adhering to the surface of the cover
- low $A / A_{\text {|| }}$ ratio: indicates the hydrolytic cleavage of peptide bonds of collagen - $A_{I I I}$ band completely disappears: indicates the presence of collagen populations with disorganized structure.

\section{Materials Added to Parchment Identified by XRF - Figure 19}
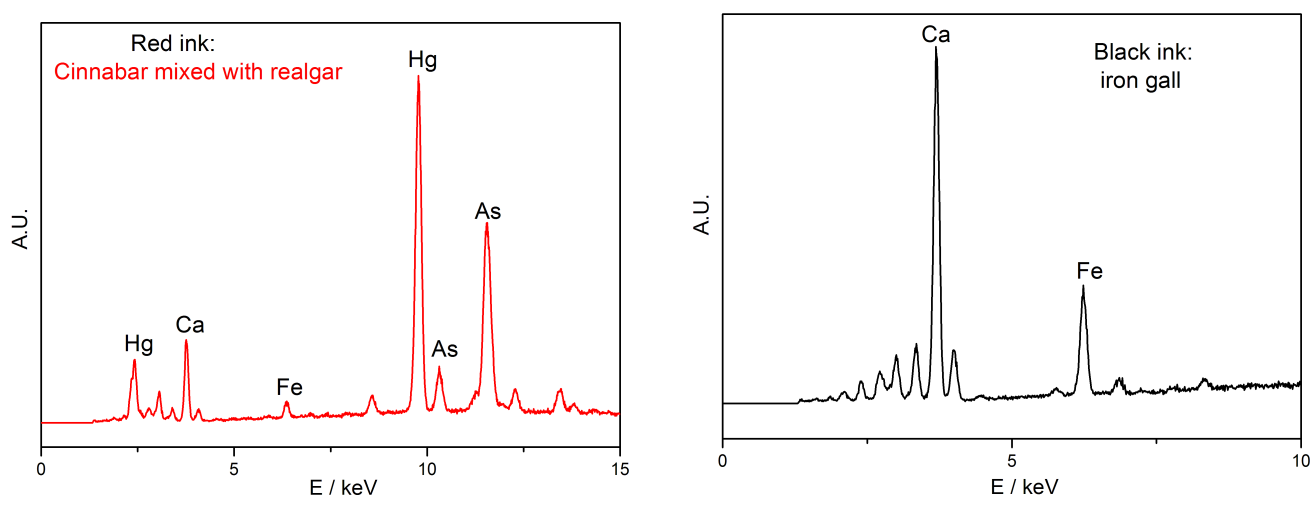


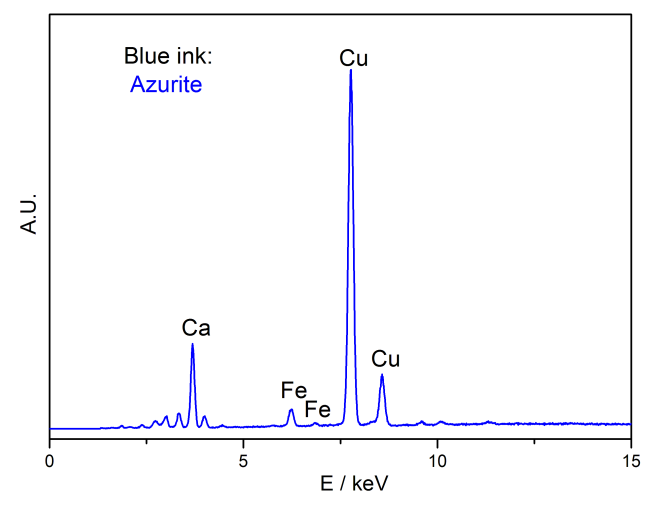

Figure 19. XRF spectra of inks applied to the parchment cover (I 39622). Red ink: mixture of cinnabar $(\mathrm{HgS})$ and realgar $\left(\mathrm{As}_{4} \mathrm{~S}_{4}\right)$; blue ink: based on $\mathrm{Cu}$ (probably azurite); black ink: ferogallic (identification based on the presence of Fe in the XRF spectrum). The presence of calcium carbonate on the parchment surface is confirmed.

\section{CONCLUSIONS}

Over 50 bindings in alum-tawed (white) leather, parchment and reused parchment were analyzed in situ using specific non-invasive or micro-invasive analysis methods such as visual and microscopic analyses, thermal microscopy (imageMHT method), attenuated total reflection (ATR) Fourier transform infrared spectroscopy (FTIR) spectroscopy and X-ray Fluorescence Spectrometry (XRF). Based on these results, conservation sheets have been drawn up including damage status, threats and conservation recommendations for each investigated bookbinding. The main findings of the study refer to the ornaments for white leather and parchment bindings as well as identification of materials, inks and pigments and evaluation of damage status of parchment and leather.

For both alum-tawed leather and parchment, the structural heterogeneity is quite high suggesting the presence of several collagen populations with distinct thermal stability: collagen "stabilized" by the reaction with aluminum salts or by dehydration and consequent crosslinking, "free" collagen resulting from the "detanning" process, "destabilized" collagen from hydrolytic and oxidative processes and pregelatinized and gelatinized collagen fractions in case of parchments. The thermally unstable, pregelatinized and gelatinized fractions of collagen are susceptible to being affected by high and/or oscillating $\mathrm{RH}$ in the storage, consultation or exposure spaces, as well as by wet conservation or restoration treatments. Such inappropriate storage/exhibition/use conditions and/or conservation treatments represent a high risk of solubilization of unstable fractions, appearance of sticky areas or crack formation (craquelé appearance), loss of collagen.

ATR-FTIR parameters such as $A_{1} / A_{\|}$ ratio were used to characterize the molecular alterations of collagen structure. For example, low $A_{1} / A_{\|}$ratio indicates the hydrolytic cleavage of peptide bonds of collagen, while the reduction or disappearance of $A_{\mathrm{III}}$ band indicates the presence of collagen populations with disorganized structure.

Alum was identified by both ATR-FTIR and XRF techniques. Identification of black ferogallic ink was based on the presence of Fe in the XRF spectrum. Red, blue and gold inks were also identified. In most cases red ink was a mixture of cinnabar ( $\mathrm{HgS})$ and realgar $\left(\mathrm{As}_{4} \mathrm{~S}_{4}\right)$, blue ink was a copper-based pigment (most probably azurite), while golden ink was liquid gold. Calcium carbonate originating from the manufacturing process, aluminosilicates from the dust (dirt) adhering to the surface of the covers are also present on the surface of all bindings.

Two conservation sheets are included at the end of this paper as exemplifying material.

\section{Acknowledgements}

The study was funded by the Ministry of Research and Innovation and UEFISCDI within the project: Natural leather for contemporary design, LeatherCoDe, Contract no. $176 \mathrm{Cl} / 2018$, PN-III-CERC-CO-Cl-2018. 


\section{REFERENCES}

1. Mouren, R., Canart, P., Choulis, K., Förstel, C., La description des reliures orientales: conservation, aspects juridiques et prise de vue. Études réunies par Raphaële Mouren dans le cadre du projet STUDITE, London, Archetype Publications, 2013.

2. Greek Byzantine manuscripts from the Romanian Academy Library, available at https://www.e-corpus.org.

3. Kopeczny, Z., Ferecături de cărți medievale în descoperirile arheologice din Transilvania, ArhMed, 2007, 6, 141-166.

4. Larsen, R. (ed.), Improved damage assessment of parchment (IDAP): assessment, data collection and sharing of knowledge, Luxemburg: The European Commission, 2007.

5. Badea, E., Poulsen Sommer, D.V., Mühlen Axelsson, K., Della Gatta, G., Larsen, R., Standardised methods for damage ranking in parchment: from microscopic evaluation to collagen denaturation assessment, e-Preservation Science, 2012, 9, 97-109.

6. Badea, E., Carșote, C., I segreti della pergamena del testamento di Marco Polo/The secrets of the parchment containing Marco Polo's will, in Tiziana Plebani (ed.), “Ego Marcus Paulo volo et ordino - I segreti del testamento di Marco Polo// Ego Marcus Paulo volo et ordino - The secrets of Marco Polo's will", Scrinium S.p.A, Venice - Mestre, Italy, 2017, 247 - 271.

7. Carșote, C., Badea, E., Petroviciu, I., Miu, L., Substratul material al documentelor. Despre meșteșug și cunoaștere, în „Pergamentul...o poveste. Fața nevăzută a documentelor emise de Cancelaria domnească în vremea lui Ștefan cel Mare“, Ed. Excelență prin Cultură, Bucharest, 2015, 37-55.

8. Carșote, C., Petroviciu, I., Georgescu, M., Investigarea nedistructivă a materialelor din Tetraevanghelul leromonahului Spiridon, în "Tetraevanghelul leromonahului Spiridon. Caligrafiat și miniat la mănăstirea Putna în 1502, din porunca lui Ștefan cel Mare", Editura Oscar Print, Bucharest, 2017, 24-45.

9. Carșote, C., Budrugeac, P., Decheva, R., Haralampiev, N., Miu, L., Badea, E., Characterization of a Byzantine manuscript by infrared spectroscopy and thermal analysis, Revue Roumaine de Chimie, 2014, 59, 6-7, 429-436.
10. Larsen, R., Vest, M., Nielsen, K., Determination of hydrothermal stability (shrinkage temperature) of historical leathers by Micro Hot Table technique, J Soc Leath Tech Ch, 1993, 77, 151-156.

11. Larsen, R., Poulsen, D., Vest, M., The hydrothermal stability (shrinkage activity) of parchment measured by the micro hot table method (MHT). In: Microanalysis of Parchment, edited by R. Larsen, london: Archetype Publications, 2002, 93-99.

12. Larsen, R., Poulsen Sommer, D.V., Mühlen Axelsson, K., Scientific approach in conservation and restoration of leather and parchments objects in archives and libraries. In: P. Engel Ed. New Approaches to Book and Paper Conservation-Restoration, Verlag Berger, Horn/Wien, 2011, 239-258.

13. Badea, E., Șendrea, C., Carșote, C., Adams, A., Blümich, B., lovu, H., Unilateral NMR and thermal microscopy studies of vegetable tanned leather exposed to dehydrothermal treatment and light irradiation, Microchem J, 2016, 129, 158-165, https://doi.org/10.1016/j.microc.2016.06.013.

14. Badea, E., Della Gatta, G., Usacheva, T., Effects of temperature and relative humidity on fibrillar collagen within parchment: a micro Differential Scanning Calorimetry (micro DSC) study, Polym Degrad Stab, 2012, 97, 346-353, https://doi.org/10.1016/j. polymdegradstab.2011.12.013.

15. Badea, E., Usacheva, T., Della Gatta, G., The use of differential scanning calorimetry to characterise collagen deterioration in parchment, Rossiiskii Khimicheskii Zhurnal - Zhurnal Rossiiskogo Khimicheskogo Obshchestva im. D.I. Mendeleeva (Russian Chemistry Journal), 2015, V. 59, 28-41.

(C) 2018 by the author(s). Published by INCDTPICPI, Bucharest, RO. This is an open access article distributed under the terms and conditions of the Creative Commons Attribution license (http:// creativecommons.org/licenses/by/4.0/). 